\title{
KAJIAN AKTIVITAS ANTIOKSIDAN DAN TINGKAT KESUKAAN TEH DAUN INSULIN (Smallanthus sonchifolius) PADA BERBAGAI SUHU PENGERINGAN
}

\author{
[Study of Antioxidant Activity and Acceptance of Insulin Leaves Tea (Smallanthus Sonchifolius) on \\ Various Drying Temperatur]
}

St. Yatun Naimah, Nazaruddin, dan Siska Cicillia*

Fakultas Teknologi Pangan dan Agroindustri, Universitras Mataram, Nusa Tenggara Barat

Jl. Majapahit No.58 Mataram

*E-mail: siskacicilia@unram.ac.id

Diterima 10 Juli 2020 / Disetujui 09 Februari 2021

\begin{abstract}
The purpose of this research was to determine the effect of drying temperature on antioxidant activity of insulin leaves. This study was designed using a Randomized Block Design (RAK) with 6 treatments, drying temperature, namely $\mathrm{T1}\left(35^{\circ} \mathrm{C}\right), \mathrm{T} 2\left(40^{\circ} \mathrm{C}\right), \mathrm{T3}\left(45^{\circ} \mathrm{C}\right), \mathrm{T} 4\left(50^{\circ} \mathrm{C}\right), \mathrm{TS}\left(55^{\circ} \mathrm{C}\right)$, and $\mathrm{T} 6\left(60^{\circ} \mathrm{C}\right)$ and it was repeated 3 times. The parameter observed were chemical properties (moisture content, antioxidant activity), physical property (value of ${ }^{\circ} \mathrm{Hue}$ ) and organoleptic properties (color, taste and odor) of insulin leaves tea. Data from observations were analyzed using Anova at 5\% significance level using Co-stat software. If there was significant differences, a further Polynomial Orthogonal (for chemical properties) and Honestly Significant Difference (HSD) (for value of ${ }^{\circ} H u e$ and organoleptic properties). The results showed increasing of drying temperature cause significant reduction in moisture content, antioxidant activity and organoleptic value of tea. The third treatment $\left(45^{\circ} \mathrm{C}\right)$ was the best treatment with moisture content value of $17.14 \%$, antioxidant activity $35 \%$, and can be accepted by panelist.
\end{abstract}

Keywords: antioxidant activity, drying temperature, insulin leaves

\section{ABSTRAK}

Tujuan penelitian ini adalah mengetahui efek suhu pengeringan terhadap aktivitas antioksidan dan sifat organoleptik teh daun insulin. Penelitian ini dilakukan dengan Rancangan Acak Kelompok (RAK) dan 6 perlakuan yaitu suhu pengeringan $35^{\circ} \mathrm{C}, 40^{\circ} \mathrm{C}, 45^{\circ} \mathrm{C}, 50^{\circ} \mathrm{C}, 55^{\circ} \mathrm{C}$, dan $60^{\circ} \mathrm{C}$ dengan 3 kali ulangan. Parameter yang diamati meliputi sifat kimia (kadar air, aktivitas antioksidan), sifat fisik (warna), dan sifat organoleptik (aroma, warna, dan rasa). Hasil pengamatan dianalisis dengan Anova pada taraf 5\% menggunakan Co-stat serta uji lanjut Polinomial Orthoginal (sifat kimia) dan Beda Nyata Jujur (BNJ) (sifat fisik dan organoleptik). Hasil penelitian menujukkan bahwa kenaikan suhu pengeringan pada pembuatan teh daun insulin menyebabkan penurunan pada kadar air, aktivitas antioksidan, dan nilai organoleptik teh tersebut. Suhu pengeringan $45^{\circ} \mathrm{C}$ merupakan perlakuan terbaik dengan nilai kadar air $17,41 \%$; aktivitas antioksidan $35 \%$; dan masih disukai panelis.

Kata kunci: aktifitas antioksidan, daun insulin, suhu pengeringan

\section{PENDAHULUAN}

Teh merupakan salah satu jenis minuman yang disukai masyarakat dari semua kalangan karena memiliki efek yang menyegarkan. Teh diketahui mempunyai banyak manfaat bagi kesehatan seperti sebagai antioksidan yang dapat menangkal radikal bebas. Salah satu jenis antioksidan yang terdapat pada teh adalah flavonoid yang bertindak sebagai antikarsinogenik, dan hipokolesterolemik. Beberapa peneliti lain juga menyebutkan bahwa teh bersifat hipoglikemik dan menghambat aterosklerosis. Beberapa komponen senyawa kimia dalam teh dapat mempengaruhi sifat fisik teh seperti warna, rasa, dan aroma. Menurut Machmud (2006), konsumsi teh terbanyak berasal dari Amerika, Jepang dan Eropa sebanyak 2,5 kg/kapita/tahun sedangkan konsumsi teh orang Indonesia berkisar $0,8 \mathrm{~kg} / \mathrm{kapita} /$ tahun.

Belakangan ini produk teh tidak hanya dihasilkan dari daun teh Camelia siensis saja, beberapa tanaman sudah diolah menjadi teh seperti daun insulin. Daun insulin (Smallanthus sonchifolius) merupakan tanaman yang berasal dari lereng 
pegunungan Andes, Amerika latin. Daun insulin memiliki efek antidiabetik karena dapat menghambat proses glikogenolisis dan glukoneogenesis dan menstimulasi proses sekresi insulin dari sel $\beta$-pankreas. Insulin adalah berfungsi mempercepat pelepasan glukosa, meningkatkan sensifitas reseptor insulin, dan meningkatkan penyerapan glukosa oleh jaringan atau organ sehingga tidak terjadi penumpukan glukosa dalam darah. Daun insulin juga mengandung senyawa aktif seperti fenol, klorogenik, caffeonylquinic, fructooligosacarida, flavonoid, fenolik dan fruktan. Kandungan caffeonylquinic mengandung senyawa aktif yang menghambat enzim a-glukosidase sehingga menurunkan kadar glukosa darah. Kandungan fruktan terbukti sebagai prebiotik yang menstimulasi pertumbuhan bifido bacterium dengan dosis 3-10 gr/hari dapat merangsang penurunan tekanan darah serta memiliki efek hipoglikemik (Pahlawan, 2016).

Daun insulin digunakan untuk pengobatan penyakit diabetes mellitus (DM) menggunakan air rebusan atau ekstraknya. Menurut Chon (2000), daun insulin mengandung dua komponen utama yang memiliki peran hipoglikemik yaitu flavonoid dan seskuiterpen yang terdapat di daun. Flavonoid adalah salah satu senyawa yang memiliki aktivitas antioksidan tinggi yang berkaitan dengan aktivitas antidiabetes. Senyawa ini mampu mencegah kerusakan yang disebabkan oleh spesies oksigen reaktif sehingga dapat mencegah penyakit degeneratif seperti kanker dan DM.

Penelitian tentang aktivitas antioksidan pada teh daun insulin berbagai kisaran suhu pengeringan belum pernah dilakukan akan tetapi menurut penelitian Azmi (2015) pembuatan ekstrak daun insulin dengan etanol $70 \%$ menghasilkan ekstrak cair dan ekstrak kering yang dapat menurunkan kadar gula darah. Pada teh yang memiliki sifat hipoglikemia yang sama dengan teh daun insulin yaitu menurut Wahyudi, dkk (2013) pada pembuatan teh daun kelor dan rosella dengan perbandingan $1: 2$ dibuat dengan pengeringan pada suhu $60^{\circ} \mathrm{C}$ selama 120 menit merupakan hasil terbaik dengan aktivitas antioksidan tertinggi sebesar 64,5\%. Berdasarkan penelitian Adri dan Hersoelistyarini (2013), pengeringan teh daun sirsak selama 150 menit pada $50^{\circ} \mathrm{C}$ menghasilkan teh dengan aktivitas antioksidan yang tinggi dan nilai $\mathrm{EC}_{50}$ sebesar $117,86 \mu \mathrm{g} / \mathrm{mL}$. Menurut Dewi (2017) menyatakan bahwa teh daun katuk dengan pengeringan suhu $50^{\circ} \mathrm{C}$ dengan lama pengeringan 120 menit menghasilkan antioksidan $31,29 \mu \mathrm{g} / \mathrm{ml}$.

\section{BAHAN DAN METODE}

\section{BAHAN}

Bahan-bahan yang digunakan adalah daun insulin, aquades, metanol, $\mathrm{HCL}$ pekat, DPPH 0,1 mM dan $\mathrm{NaOH} 10 \%$ sedangkan alat-alat yang digunakan adalah timbanagan analitik, oven, blender, tabung reaksi dan raknya, spektrofotometer UV-vis, pipet ukur, rubber bulb, erlenmeyer, vortex, cabinet dryer, cawan porselin, dan desikator.

\section{Metode}

Metode penelitian ini adalah metode eksperimental dengan Rancangan Acak Kelompok (RAK) dengan perlakuan suhu pengeringan yaitu $\mathrm{T} 1=35^{\circ} \mathrm{C}, \mathrm{T} 2=40^{\circ} \mathrm{C}$, T3 $=45^{\circ} \mathrm{C}, \mathrm{T} 4=50^{\circ} \mathrm{C}, \mathrm{T} 5=55^{\circ} \mathrm{C}$, dan $\mathrm{T} 6=$ $60^{\circ} \mathrm{C}$ yang diulang sebanyak 3 kali. Data hasil pengamatan dianalisis dengan Anova 5\% menggunakan Co-stat. Uji lanjut yang digunakan adalah Polinomial Orthoginal (sifat kimia) dan Beda Nyata Jujur (BNJ) (sifat fisik dan organoleptik) pada taraf $5 \%$.

\section{Pelaksanaan Penelitian}

\section{Pembuatan Teh Daun Insulin}

Pembuatan teh daun insulin dimulai dengan sortasi, pencucian dan penirisan, pelayuan dengan waktu 2 jam, pengeringan dengan variasi suhu $35^{\circ} \mathrm{C} 40^{\circ} \mathrm{C} 45^{\circ} \mathrm{C} 50^{\circ} \mathrm{C}$ $55^{\circ} \mathrm{C} \quad 60^{\circ} \mathrm{C}$ selama 150 menit dan penggilingan.

\section{Parameter Analisis}

Parameter yang diamati adalah sifat kimia (kadar air, aktivitas antioksidan), sifat 
fisik (warna), organoleptik (rasa, aroma dan warna).

\section{HASIL DAN PEMBAHASAN}

\section{Kadar Air}

Pola kecenderungan suhu pengeringan terhadap kadar air pada teh daun insulin dapat dilihat pada Gambar 1.

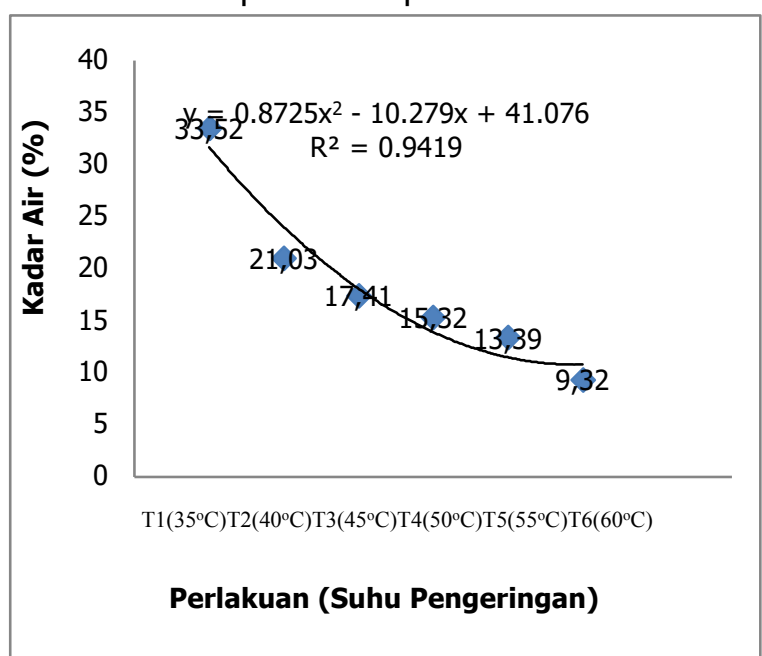

Gambar 1. Kadar Air Teh Daun Insulin pada Berbagai Perlakuan Suhu Pengeringan

Gambar 1 menunjukkan pengaruh suhu pengeringan terhadap kadar air teh daun insulin. Pola regresi yang terbentuk adalah kuadratik dengan persamaan $\mathrm{y}=$ $0,8725 x^{2}-10,2792 x+41,076$ dengan koefisien determinasi (KD) $R^{2}=0,9419$. Nilai 0,8725 merupakan nilai yang menunjukkan arah regresi kuadratik yaitu bernilai positif. Nilai positif menunjukkan hubungan positif pada suhu pengeringan dengan penurunan kadar air teh daun insulin yang konsisten. Peningkatan suhu pengeringan penurunan kadar air teh daun insulin rata-rata sebesar 0,8725 . Pada pola kuadratik menunjukkan bahwa akan terjadi penurunan kadar air. Nilai 10,2792 yaitu nilai yang menunjukkan arah regresi linier yang bernilai positif. Nilai positif menunjukkan adanya hubungan positif pada suhu pengeringan dan penurunan kadar air teh daun insulin yang konsisten. Nilai 14,07 merupakan nilai konstanta atau intercept dimana pada titik $\mathrm{x}=0$, nilai kadar air 14,07. Nilai koefisien determinan (KD) sebesar 0,941 dikonversikan ke persen (\%) menjadi $94,1 \%$ menunjukkan $94,1 \%$ terjadinya penurunan kadar air teh daun sebesar dipengaruh oleh suhu pengeringan.

Suhu pengeringan yang tinggi menyebabkan molekul air yang menguap semakin banyak sehingga terjadi penurunan kadar air. Menurut Winarno (1997) dan Desrories (1988), peningkatan suhu pengeringan menyebabkan kemampuan bahan untuk melepas air dari permukaan semakin besar dan jumlah air yang diuapkan semakin banyak sehingga kadar air dan bobot bahan menurun.

\section{Aktivitas Antioksidan}

Pola kecenderungan suhu pengeringan terhadap aktivitas antioksidan teh daun insulin dapat pada Gambar 2.

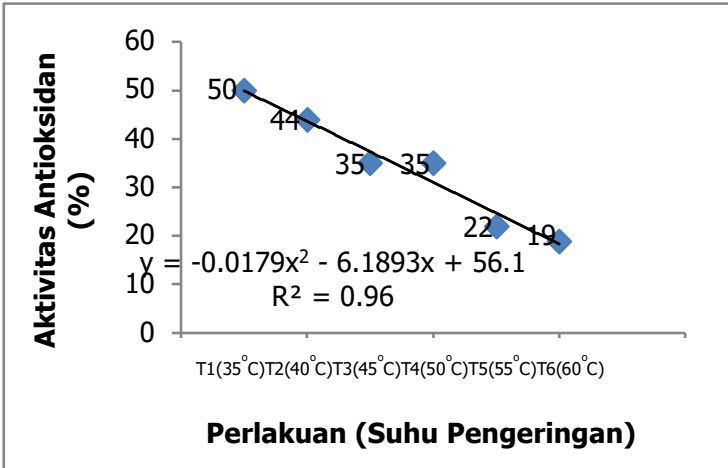

Gambar 2. Aktivitas Antioksidan Teh Daun Insulin pada Berbagai Perlakuan Suhu Pengeringan

Gambar 2 menunjukkan bahwa adanya pengaruh pada suhu pengeringan terhadap aktivitas antioksidan teh daun insulin, dimana bahwa semakin tinggi suhu pengeringan maka pola regresi yang terbentuk adalah kuadratik dengan persamaan $y=-0,017 x^{2}-6,189 x+56,1$ dengan koefisien determinan $R^{2}=0,96$. Nilai $-0,017$ merupakan nilai yang menunjukkan arah regresi kuadratik yaitu bernilai negatif. Nilai negatif menunjukkan adanya hubungan negatif antara suhu pengeringan terhadap aktivitas antioksidan teh daun insulin. Hal ini menunjukkan peningkatan suhu pengeringan maka akan menurunkan aktivitas antioksidan 
teh daun insulin. Pada pola kuadratik menunjukkan bahwa akan terjadi penurunan aktivitas antioksidan sesuai standar yang diinginkan. Nilai koefisien yang diperoleh yaitu sebesar $R^{2}=0,96$. Jika nilai koefisien determinasi dikonfersi ke dalam persen maka akan dihasilkan nilai sebesar $96 \%$ dimana $96 \%$ penurunan aktivitas antioksidan teh daun insulin dipengaruhi oleh suhu pengeringan, sedangkan $4 \%$ dipengaruhi oleh faktor lain.

Nilai purata yang dihasilkan oleh aktivitas antioksidan yaitu pada perlakuan $35^{\circ} \mathrm{C}$ menghasilkan nilai sebesar $50 \%$; pada suhu $40^{\circ} \mathrm{C}$ menghasilkan nilai sebesar $44 \%$; pada suhu $45^{\circ} \mathrm{C}$ menghasilkan nilai aktivitas antioksidan sebesar $35 \%$; pada suhu $50^{\circ} \mathrm{C}$ menghasilkan nilai sebesar 35\%; pada suhu $55^{\circ} \mathrm{C}$ menghasilkan nilai sebesar $22 \%$ dan pada suhu $60^{\circ} \mathrm{C}$ menghasilkan nilai sebesar $19 \%$

Kandungan antioksidan yang terdapat pada teh yaitu fenol dan flavonoid yang sangat dipengaruhi oleh suhu pengeringan. Hal ini terjadi karena suhu pengeringan yang tinggi menyebabkan kandungan polifenol, fenol dan flavonoid pada bahan cepat menguap sehingga terjadi penurunanan senyawa fenol. Panas atau suhu tinggi yang disertai dengan pemanasan dalam waktu yang lama dapat menyebabkan kerusakan pada komponen penyusun yang terkandung pada teh daun insulin. Hal ini sesuai dengan pendapat Rohdiani (2001) menyatakan bahwa proses pengeringan dapat menurunkan zat aktif yang terkandung dalam bahan pangan sehingga berpengaruh pada aktivitas antioksidan. Hasil yang sama ditunjukkan dengan penelitian Sari (2015) pada teh herbal daun katuk yang menyatakan bahwa semakin tinggi suhu menyebabkan penurunan aktivitas antioksidan, karena terjadinya kerusakan oleh panas dan pemasakan (Apriadji, 2008). Pemanasan akan mempercepat oksidasi dan menurunkan aktivitas antioksidan dengan tingkatan yang berbeda sesuai dengan jenis dan komponen yang berperan dalam antioksidan (Muawanah, 2012).

\section{Uji Warna ('Hue)}

Uji warna dapat dilakukan menggunakan colorimeter yang dapat mengidentifikasi warna dengan beberapa tingkatan yaitu nilai L (lightness/kecerahan), a (merah), b (kekuningan pada suatu produk. Nilai $\mathrm{L}$ menunjukkan tingkat kecerahan suatu bahan.

Pengaruh suhu pengeringan terhadap kecerahan teh daun insulin dapat dilihat pada Gambar 3.

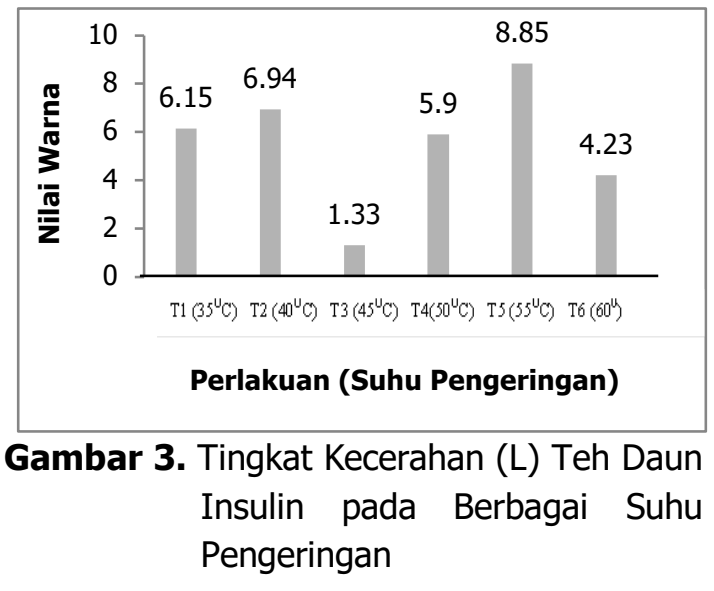

Gambar 3 menunjukkan bahwa suhu pengeringan tidak memberikan pengaruh yang berbeda nyata terhadap nilai $L$ teh daun insulin. Nilai $L$ yang paling tinggi diperoleh oleh pada perlakuan suhu pengeringan $55^{\circ} \mathrm{C}$ sebesar 8,85 dan tingkat kecerahan terendah pada terdapat pada perlakuan suhu pengeringan $45^{\circ} \mathrm{C}$ sebesar 1,33. Semakin kecil nilai $L$ menunjukkan warna teh semakin gelap. Perubahan warna teh daun insulin disebabkan oleh degradasi pigmen pada daun insulin. Klorofil terdegradasi menjadi feofitin, pigmen penyebab warna cokelat. Menurut Towaha (2013), tanin juga mengalami oksidasi menghasilkan senyawa teaflavin (pigmen penyebab warna kuning) dan thearubigin (pigmen penyebab warna merah). Hal ini juga didukung oleh Susanto dan Saneto (1994) dalam Martunis (2012) dan Yamin, dkk (2017), pengeringan menyebabkan banyak perubahan warna bahan karena degradasi pigmen. 


\section{Warna (Metode Hedonik)}

Warna merupakan salah satu sifat fisik yang paling pertama dilihat oleh mata dan sangat penting dalam penilaian suatu produk pangan seperti teh. Pengaruh suhu pengeringan terhadap hedonik warna teh daun insulin dapat dilihat pada Gambar 4.

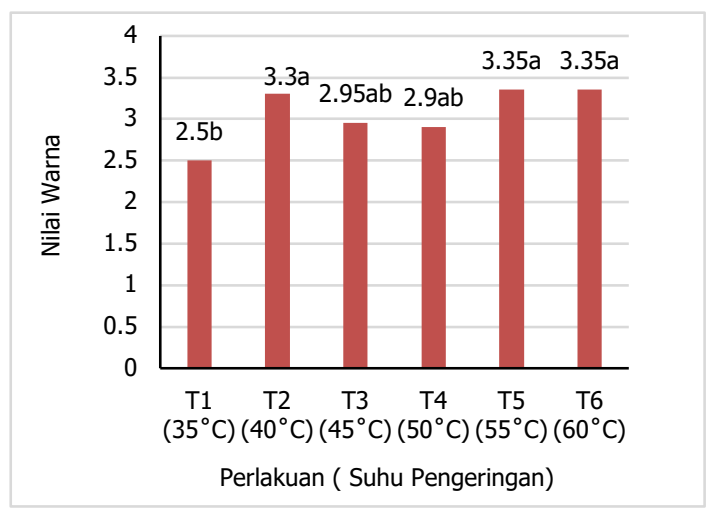

Gambar 4. Nilai Hedonik Warna Teh Daun Insulin pada Berbagai Suhu Pengeringan

Gambar 4 menunjukkan bahwa pengaruh suhu pengeringan memberikan pengaruh yang berbeda nyata terhadap warna teh daun insulin secara hedonik. Semakin tinggi suhu pengeringan maka tingkat kesukaan semakin menurun dikarenakan warna yang dihasilkan terlalu pekat. Proses pengeringan menyebabkan degradasi klorofil dan menghasilkan pigmen penyebab warna cokelat (feofitin). Hasil ini juga didukung oleh Wirawan (2012) dan Nafisah dan Widyaningsih (2018) yang menyatakan bahwasemakin tinggi suhu pengeringan menyebabkan warna seduhan teh semakin gelap.

\section{Rasa (Metode Hedonik)}

Rasa adalah salah satu penentu tingkat penerimaan konsumen pada suatu produk. Penilaiannya cenderung subyektif dan sangat dipengaruhi oleh kesukaan individual terhadap produk. Pengaruh suhu pengeringan terhadap hedonik rasa teh daun insulin dapat dilihat pada Gambar 5. 
Versi Online:

http://www.profood. unram.ac.id/index.php/profood e-ISSN: 2443-3446

teh daun insulin dapat dilihat pada Gambar 6.

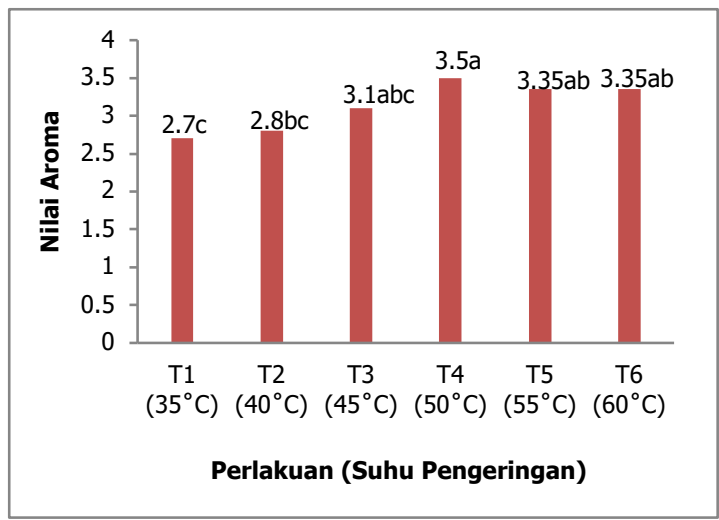

Gambar 6. Nilai Hedonik Aroma Teh Daun Insulin pada Berbagai Suhu Pengeringan

Gambar 6 menunjukkan bahwa uji hedonik aroma yang dihasilkan pada teh daun insulin dengan nilai berkisar 2,7-3,5 dengan kritetia tidak disukai sampai agak disukai. Nilai tertinggi pada suhu $50^{\circ} \mathrm{C}$ dengan nilai sebesar 3,5 dan nilai terendah pada suhu $35^{\circ} \mathrm{C}$ dengan nilai sebesar 2,7. Hal ini menunjukkan bahwa peningkatan suhu pengeringan menyebabkan penurunan nilai aroma teh daun insulin. Hal ini disebabkan oleh hilangnya komponen volatil selama proses pengolahan terutama panas. Aroma teh dibentuk oleh minyak atsiri yang mudah menguap (Ciptadi dan Nasution, 1979), komponen pembentuk aroma teh adalah minyak atsiri yang bersifat mudah menguap dan bersifat reduksi sehingga dapat menghasilkan aroma harum pada teh.

\section{KESIMPULAN}

1. Suhu pengeringan memberikan pengaruh yang berbeda nyata terhadap semua parameter kecuali tingkat kecerahan (L) teh daun insulin.

2. Peningkatan suhu pengeringan menyebabkan penurunan kadar air, aktivitas antioksidan, dan nilai organoleptic teh daun insulin.

3. Perlakuan terbaik pada pembuatan teh daun insulin adalah dengan suhu
Pro Food (Jurnal IImu dan Teknologi Pangan) Vol 6 No. 2 November 2020 ISSN: 2443-1095

pengeringan $45^{\circ} \mathrm{C}$ dengan nilai kadar air sebesar $15,82 \%$ dan aktivitas antioksidan dengan nilai sebesar $35 \%$ dan sifat organoleptik yang dapat diterima oleh panelis.

\section{DAFTAR PUSTAKA}

Adri,D., Hersoelistyorini, W. 2013. Aktivitas Antioksidan dan Sifat Organoleptik Teh Daun Sirsak Berdasarkan Varian Lama Pengeringan. Jurnal Pangan dan Gizi. 4(7): 1-13.

Azmi, A. 2015. Efek Ekstrak Daun Insulin (Smallantus sonchifolius) terhadap Kadar Glukosa Darah, Berat Badan dan Low Density Lipoprotein pada Tikus yang Diinduksi Steptozotosin. Skripsi Pendidikan Dokter. Universitas Islam Negeri Syarif Hidayatullah. Jakarta.

BSN. 2013. SNI 3836-2013: Teh Kering Dalam Kemasan. Badan Standar Nasional. Jakarta

Desrories, N. W. 1969. Teh Technology of Food Preservation. Diterjemahkan oleh Muljohardjo, M. 1988. Teknologi Pengawetan Pangan. Universitas Indonesia Press. Jakarta.

Dewi, W. K., Harun, N., dan Zalfiatri, Y. 2017. Pemanfatan Daun Katuk (Sauropus adrogynus) dalam Pembuatan Teh Herbal dengan Variasi Suhu Pengeringan. Mahasiswa (JOM) Bidang pertanian, 4(2): 1-9.

Nafisah, D. Widyaningsih, TD. 2018. Kajian Metode Pengeringan dan Rasio Penyeduhan pada Proses Pembuatan Teh Cascara Kopi Arabika (Coffea Arabika L.). Jurnal Pangan dan Agroindustri. (6)3: 37-43.

Pahlawan, P.P., dan D. Oktavia. 2016. Manfaat Daun Insulin (Smallantus sonchifolius) Sebagai Diabetes.Majority. 5(4): 133-137.

Sari, M. A. 2015. Aktivitas Antioksidan Teh Daun Alpukat (Presea Americana mill) dengan Variasi Teknik dan Lama Pengeringan. Skripsi. Fakultas Keguruan dan Ilmu Pendidikan. 
Universitas Muhammadiyah Surakarta. Surakarta.

Wahyudi, H.A, Mustofa.Y, A., dan Widanti. 2013. Aktivitas Antioksidan Teh Daun Kelor (Moringa oliefera) Rosella (Hibiscus Sabdariffa l.) dengan Varian Lama Pengeringan. Jurnal Teknologi dan Industri Pangan. 3(2): 106-112.

Winarno, F. G. 1997. Kimia Pangan dan Gizi. Gramedia Pustaka Utama. Jakarta.

Yamin, M., Ayu. D. F. dan Hamzah F. 2017. Lama Pengeringan Terhadap Aktivitas Antioksidan dan Mutu Teh Herbal Daun Ketepeng Cina (Cassia alata L.) Jurnal JOM FAPERTA. 4(2): 1-15. 